Supporting Information

\title{
Terpyridyl Ruthenium Complexes \\ Functionalized with Conjugated Heterocycles for Panchromatic Dye-Sensitized Solar Cells
}

\author{
Chia-Yuan Chen, ${ }^{* a, b}$ Yu-Ming Feng, ${ }^{b}$ Tsung-Yu Wu, ${ }^{b}$ Yu-Chi Liu, ${ }^{b}$ \\ Shih-Yun Chen, ${ }^{b}$ Ting-Yi Lin, ${ }^{b}$ Hui-Hsu Gavin Tsai ${ }^{* a, b}$ and Chun-Guey Wu ${ }^{\star a, b}$
}

a. Research Center of New Generation Light Driven Photovoltaic Modules National Central University, Taoyuan 32001, Taiwan, R.O.C.

b. Department of Chemistry, National Central University, Taoyuan 32001, Taiwan, R.O.C.

E-mail address of Professor Chia-Yuan Chen: chiayuan@ncu.edu.tw

E-mail address of Professor Hui-Hsu Gavin Tsai: hhtsai@cc.ncu.edu.tw

E-mail address of Professor Chun-Guey Wu: t610002@cc.ncu.edu.tw 


\section{Synthetic Procedures of Esterified Ligands (L36, L39 and L41), and the Ru Complexes (CYC-36, CYC-39 and CYC-41)}

1.1. Materials and Molecular Characterization. All reagents and solvents for material syntheses and device fabrication were obtained from the commercial sources and used as received unless specified. The molecular structures of new ruthenium complexes (CYC-36, CYC-39 and CYC-41) were identified with NMR spectroscopy $\left({ }^{1} \mathrm{H}\right.$ and $\left.{ }^{13} \mathrm{C}\right)$, HRESI-TOF-MS (negative ion) and elemental analysis. The NMR spectra were recorded in deuterated methanol $\left(\mathrm{MeOH}-\mathrm{d}_{4}\right)$ or dimethyl sulfoxide (DMSO- $\mathrm{d}_{6}$ ) with the Bruker $500 \mathrm{MHz}$ NMR spectrometer. The HRESI-TOF-MS spectra were obtained using the SCIEX QSTAR®X MS. The elemental analyses were carried out with the Heraeus CHN-O-S RapidF002 analysis system. Absorption spectra of the complexes in N,Ndimethylformamide (DMF) were measured using the Hitachi UH4100 spectrometer. Electrochemical properties of the complexes (concentration of 1 $\mathrm{mM}$ ) in anhydrous DMF were studied in a single-compartment, three-electrodes cell. The reference electrode was $\mathrm{Ag} / \mathrm{Ag}^{+}$, and the supporting electrolyte was $0.1 \mathrm{M}$ tetrabutylammonium perchlorate $\left(\mathrm{TBAClO}_{4}\right)$. The square-wave voltammograms of the complexes were recorded using a potentiostat / galvanostat (Autolab PGSTAT 30, Eco-Chemie, the Netherlands). The potential step increment and frequency was $1 \mathrm{mV}$ and $25 \mathrm{~Hz}$, respectively. Ferrocene was used as an external standard for potential calibration (0.63 V vs. NHE).

1.2. Synthesis of Esterified Ligands (L36, L39 and L41). The synthetic routes of the new tpy-based ligands are outlined in Figure S1. The detailed procedures and characterization data are provided in the following. 


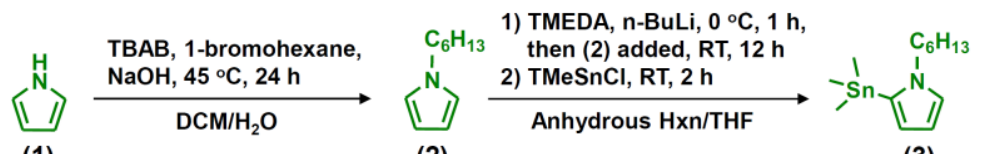

(1)

(2)

(3)
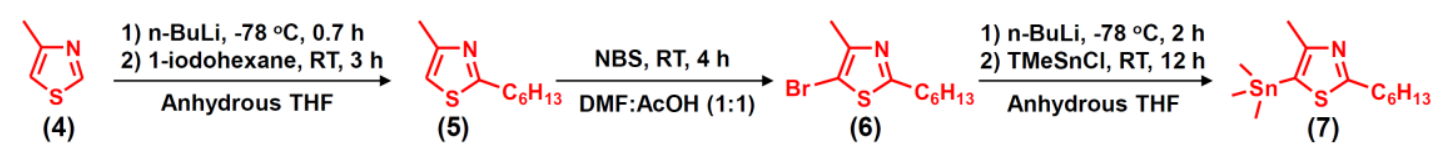

(5)

(6)

(7)

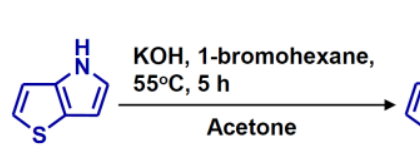

(8)

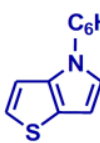

(9) 1) $\mathrm{n}-\mathrm{BuLi},-78^{\circ} \mathrm{C}, 2 \mathrm{~h}$
2) $\mathrm{TMeSnCl},-78^{\circ} \mathrm{C}, 2.5 \mathrm{~h}$
Anhydrous THF

)

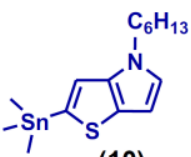

(10)

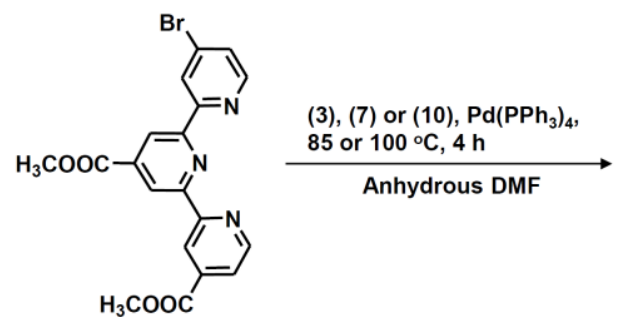

(11)

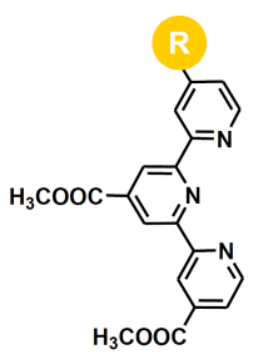

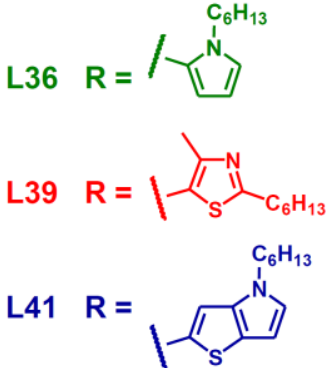

Figure S1. Synthetic routes of esterified ligands (L36, L39 and L41).

Synthesis of 1-hexyl-1H-pyrrole (2). ${ }^{51} 2.0 \mathrm{~g}(29.81 \mathrm{mmol})$ pyrrole (1), $9.7 \mathrm{~g}$ (30.1 mmol) tetra-n-butylammonium bromide (TBAB), and $4.6 \mathrm{~mL}(32.88 \mathrm{mmol})$ 1-bromohexane were mixed in $30 \mathrm{~mL}$ dichloromethane (DCM). After cooling the solution to $0{ }^{\circ} \mathrm{C}, 22.2 \mathrm{~g}(555 \mathrm{mmol}) \mathrm{NaOH}$ dissolved in $30 \mathrm{~mL}$ deionized water was added. The mixture was stirred at $45^{\circ} \mathrm{C}$ for $24 \mathrm{~h}$, followed by being cooled to room temperature (RT) and then extracted with DCM and deionized water alternatively for three times. The organic phase was collected and additionally extracted with deionized water and saturated $\mathrm{NaCl}_{(\text {aq.). }}$, respectively for two times to remove unreacted TBAB and excess $\mathrm{NaOH}$. The organic phase was collected, dried over $\mathrm{MgSO}_{4}$, filtered and concentrated under reduced pressure. The residue was purified by silica gel chromatography using ether/hexane $=1 / 9$ as an eluent to afford 1-hexyl-1H-pyrrole (2) as yellow liquid $(2.93 \mathrm{~g}, 65.0 \%$ yield). ${ }^{1} \mathrm{H}-\mathrm{NMR}\left(500 \mathrm{MHz}, \delta / \mathrm{ppm}\right.$ in $\left.\mathrm{CDCl}_{3}\right): 6.65(\mathrm{t}, J=2.0 \mathrm{~Hz}, 2 \mathrm{H}), 6.14(\mathrm{t}, J$ 
$=2.0 \mathrm{~Hz}, 2 \mathrm{H}), 3.87(\mathrm{t}, J=7.2 \mathrm{~Hz}, 2 \mathrm{H}), 1.77(\mathrm{~m}, 2 \mathrm{H}), 1.30(\mathrm{~m}, 6 \mathrm{H}), 0.89(\mathrm{t}, J=$ $6.4 \mathrm{~Hz}, 3 \mathrm{H})$.

Synthesis of 1-hexyl-2-(trimethylstannyl)-1H-pyrrole (3) $)^{\mathrm{s} 2} 1.2 \mathrm{~g}$ (10.32 $\mathrm{mmol}$ ) tetra-methylethylenediamine (TMEDA) in $40 \mathrm{~mL}$ anhydrous hexane was cooled to $0^{\circ} \mathrm{C}$, followed by adding slowly $4.2 \mathrm{~mL} n$-butyllithium solution ( $\mathrm{n}$-BuLi; $2.5 \mathrm{M}$ in hexane) under Argon at $0^{\circ} \mathrm{C}$. After stirring the solution for $1 \mathrm{~h}, 1.2 \mathrm{~g}$ (7.93 mmol) 1-hexyl-1H-pyrrole (2) was then injected and the mixture was stirred at RT for $12 \mathrm{~h}$. After cooling the solution to $0{ }^{\circ} \mathrm{C}$ again, $2.37 \mathrm{~g} \mathrm{(11.89}$ mmol) trimethyltin chloride (TMeSnCl) in $6 \mathrm{~mL}$ tetrahydrofuran (THF) was added. The solution was stirred at RT for $2 \mathrm{~h}$, following by adding deionized water to terminate the reaction. The mixture was extracted successively with hexane and saturated $\mathrm{NH}_{4} \mathrm{Cl}_{(\text {aq.) }}$ for two times. The organic phase was collected and dried over $\mathrm{MgSO}_{4}$, filtered and concentrated under reduced pressure to afford $2.4 \mathrm{~g}$ (ca. 93\% yield identified with ${ }^{1} \mathrm{H}-\mathrm{NMR}$ spectrum) crude product 1 hexyl-2-(trimethylstannyl)-1H-pyrrole (3). This intermediate was used without further purification.

Synthesis of 2-hexyl-4-methylthiazole (5). $13.5 \mathrm{~mL} \mathrm{n-BuLi} \mathrm{(2.5} \mathrm{M} \mathrm{in} \mathrm{hexane)}$ was added slowly into the solution of $3.0 \mathrm{~g}$ (30.26 mmol) 4-methylthiazole (4) in $80 \mathrm{~mL}$ anhydrous THF at $-78^{\circ} \mathrm{C}$. The mixture was stirred under Argon for 0.7 $\mathrm{h}$, followed by adding $7.0 \mathrm{~g}(33.00 \mathrm{mmol})$ 1-iodohexane. The solution was stirred successively at $-78^{\circ} \mathrm{C}$ for $1 \mathrm{~h}$ and then at RT for $3 \mathrm{~h}$. After removing THF, the residue was extracted with ethyl acetate (EA) and saturated $\mathrm{NaHCO}_{3 \text { (aq.). }}$ The organic phase was collected, dried over $\mathrm{MgSO}_{4}$, filtered and concentrated under reduced pressure. The residue was purified using silica gel 
chromatography with EA/hexane $=1 / 10$ as an eluent to afford 2-hexyl-4methylthiazole (5) as an orange-yellow liquid (2.27 g, 40.8\% yield). ${ }^{1} \mathrm{H}-\mathrm{NMR}$ (500 MHz, $\delta / p p m$ in $\left.\mathrm{CDCl}_{3}\right): 6.70(\mathrm{~s}, 1 \mathrm{H}), 2.95(\mathrm{t}, J=7.8 \mathrm{~Hz}, 2 \mathrm{H}), 2.41(\mathrm{~s}, 3 \mathrm{H})$, 1.79-1.73 (m, 2H), 1.41-1.35 (m, 2H), 1.32-1.29 (m, 4H), $0.88(\mathrm{t}, J=7.1 \mathrm{~Hz}$, $3 \mathrm{H})$.

Synthesis of 5-bromo-2-hexyl-4-methylthiazole (6). $2.05 \mathrm{~g}(11.18 \mathrm{mmol}) 2$ hexyl-4-methylthiazole (5) in $65 \mathrm{~mL}$ anhydrous DMF was mixed with $2.09 \mathrm{~g}$ (11.74 mmol) N-bromosuccinimide (NBS) in $65 \mathrm{~mL}$ glacial acetic acid $(\mathrm{AcOH})$ under Argon. The solution was stirred in dark and at RT for $4 \mathrm{~h}$. After extracting the mixture with $\mathrm{DCM}$ and saturated $\mathrm{NaCl}_{(\text {aq. }}$ for three times, the organic phase was collected, dried over $\mathrm{MgSO}_{4}$, filtered and concentrated under reduced pressure. The crude product was purified using silica gel chromatography with $\mathrm{EA} /$ hexane $=1 / 10$ as an eluent to afford 5-bromo-2-hexyl-4-methylthiazole (6) pale yellow liquid $\left(2.20 \mathrm{~g}, 75.0 \%\right.$ yield). ${ }^{1} \mathrm{H}-\mathrm{NMR}\left(500 \mathrm{MHz}, \delta / p p m\right.$ in $\left.\mathrm{CDCl}_{3}\right)$ : $2.89(\mathrm{t}, J=7.7 \mathrm{~Hz}, 2 \mathrm{H}), 2.35(\mathrm{~s}, 3 \mathrm{H}), 1.72(\mathrm{~m}, 2 \mathrm{H}), 1.42-1.34(\mathrm{~m}, 2 \mathrm{H}), 1.33-1.26$ (m, 4H), $0.88(\mathrm{t}, J=7.1 \mathrm{~Hz}, 3 \mathrm{H})$.

Synthesis of 2-hexyl-4-methyl-5-(trimethylstannyl)thiazole (7). $0.9 \mathrm{~mL} \mathrm{n}$ BuLi (2.5 M in hexane) was added slowly under Argon into the solution of $0.4 \mathrm{~g}$ (1.53 mmol) 5-bromo-2-hexyl-4-methylthiazole (6) in $8 \mathrm{~mL}$ anhydrous THF at $78^{\circ} \mathrm{C}$. After stirring the mixture at $-78^{\circ} \mathrm{C}$ for $2 \mathrm{~h}, 0.4 \mathrm{~g}(2.01 \mathrm{mmol}) \mathrm{TMeSnCl}$ in $1 \mathrm{~mL}$ THF was added into the solution. The mixture was stirred at RT for $12 \mathrm{~h}$, then extracted with $\mathrm{EA}$ and saturated $\mathrm{NaCl}_{(\text {aq.) }}$ for two times. The organic phase was dried over $\mathrm{MgSO}_{4}$, filtered and concentrated under reduced pressure to afford $0.52 \mathrm{~g}$ (ca. 95\% yield identified with ${ }^{1} \mathrm{H}-\mathrm{NMR}$ spectrum) crude product 2- 
hexyl-4-methyl-5-(trimethylstannyl)thiazole (7). This intermediate was used without further purification.

Synthesis of 4-hexyl-4H-thieno[3,2-b]pyrrole (9). $0.246 \mathrm{~g}(2.00 \mathrm{mmol})$ starting material, $4 \mathrm{H}$-thieno[3,2-b]pyrrole (8), prepared according to the literatures ${ }^{\mathrm{S}-\mathrm{S5}}$ was mixed with $0.112 \mathrm{~g}(2.00 \mathrm{mmol}) \mathrm{KOH}$ in $8 \mathrm{~mL}$ acetone. After adding $0.56 \mathrm{~mL}$ (4.00 mmol) 1-bromohexane into the mixture, the solution was refluxed for $4 \mathrm{~h}$. The solution cooled to RT was extracted successively with EA and saturated $\mathrm{NaCl}_{(\text {aq. }}$ for two times. The organic phase was collected, dried over $\mathrm{MgSO}_{4}$, filtered and concentrated under reduced pressure. The residue was purified using silica gel chromatography with $E A /$ hexane $=1 / 9$ as an eluent to afford 4-hexyl-4H-thieno[3,2-b]pyrrole (9) as a brown liquid $(0.339 \mathrm{~g}, 81.9 \%$ yield). ${ }^{1} \mathrm{H}-\mathrm{NMR}\left(500 \mathrm{MHz}, \delta / \mathrm{ppm}\right.$ in $\left.\mathrm{CDCl}_{3}\right): 7.08(\mathrm{dd}, J=5.3 \mathrm{~Hz}, J '=1.4 \mathrm{~Hz}$, $1 \mathrm{H}), 6.93(\mathrm{~d}, J=5.3 \mathrm{~Hz}, 1 \mathrm{H}), 6.86\left(\mathrm{dd}, J=2.9 \mathrm{~Hz}, J^{\prime}=1.4 \mathrm{~Hz}, 1 \mathrm{H}\right), 6.37(\mathrm{~d}, J=$ $2.9 \mathrm{~Hz}, 1 \mathrm{H}), 4.02(\mathrm{t}, J=7.1 \mathrm{~Hz}, 2 \mathrm{H}), 1.83(\mathrm{~m}, 2 \mathrm{H}), 1.31(\mathrm{~m}, 6 \mathrm{H}), 0.88(\mathrm{t}, J=7$ $\mathrm{Hz}, 3 \mathrm{H})$.

Synthesis of 4-hexyl-2-(trimethylstannyl)-4H-thieno[3,2-b]pyrrole (10). 1.5 $\mathrm{mL} n$-BuLi (2.5 M in hexane) was added slowly under Argon into the solution of $0.585 \mathrm{~g}$ (2.82 mmol) 4-hexyl-4H-thieno[3,2-b]pyrrole (9) in $20 \mathrm{~mL}$ anhydrous THF at $-78{ }^{\circ} \mathrm{C}$. After stirring the mixture at $-78{ }^{\circ} \mathrm{C}$ for $2 \mathrm{~h}, 0.843 \mathrm{~g}(4.23 \mathrm{mmol})$ TMeSnCl in $3 \mathrm{~mL}$ anhydrous THF was added into the solution. The mixture was stirred at $-78^{\circ} \mathrm{C}$ for $2.5 \mathrm{~h}$, followed by being extracted with hexane and saturated $\mathrm{NH}_{4} \mathrm{Cl}_{\text {(aq.) }}$ for two times. The organic phase was dried over $\mathrm{MgSO}_{4}$, filtered and concentrated under reduced pressure to afford $0.85 \mathrm{~g}$ (ca. 93\% yield identified with ${ }^{1} \mathrm{H}-\mathrm{NMR}$ spectrum) crude product 4-hexyl-2- 
(trimethylstannyl)-4H-thieno[3,2-b]pyrrole (10). This intermediate was used without further purification.

Synthesis of dimethyl 4"-(5-hexylcyclopenta-1,3-dien-1-yl)-[2,2':6',2"terpyridine]-4,4'-dicarboxylate (L36). The solution consisting of $1.03 \mathrm{~g} \mathrm{(2.41}$ mmol) dimethyl 4"-bromo-[2,2':6',2"-terpyridine]-4,4'-dicarboxylate prepared according to the literature, ${ }^{32} 2.23 \mathrm{~g}$ (7.10 $\left.\mathrm{mmol}\right)$ 1-hexyl-2(trimethylstannyl)-1H-pyrrole (3), and $0.083 \mathrm{~g}(0.072 \mathrm{mmol})$ tetrakis(triphenylphosphine)palladium(0) $\left(\mathrm{Pd}\left(\mathrm{PPh}_{3}\right)_{4}\right)$ in $60 \mathrm{~mL}$ anhydrous DMF was heated slowly (within $2 \mathrm{~h}$ ) to $85^{\circ} \mathrm{C}$, and then stirred at $85^{\circ} \mathrm{C}$ for $4 \mathrm{~h}$. After cooling the solution to RT, DMF was removed under reduced pressure. The residue was extracted with $\mathrm{DCM}$ and saturated $\mathrm{NaCl}_{(\text {aq.) }}$. The organic phase was collected, dried over $\mathrm{MgSO}_{4}$, filtered and concentrated under reduced pressure. The crude product was purified using silica gel chromatography with $\mathrm{DCM} / \mathrm{MeOH}=$ 25/1 as an eluent to afford $\mathrm{L} 36$ as a yellow solid $\left(0.76 \mathrm{~g}, 63.3 \%\right.$ yield). ${ }^{1} \mathrm{H}-\mathrm{NMR}$ (500 MHz, $\delta / p p m$ in $\left.\mathrm{CDCl}_{3}\right): 9.09(\mathrm{~s}, 1 \mathrm{H}), 9.05(\mathrm{~d}, J=1.4 \mathrm{~Hz}, 1 \mathrm{H}), 9.02(\mathrm{~d}, J=$ $1.4 \mathrm{~Hz}, 1 \mathrm{H}), 8.89\left(\mathrm{dd}, J=4.9 \mathrm{~Hz}, J^{\prime}=0.7 \mathrm{~Hz}, 1 \mathrm{H}\right), 8.72(\mathrm{~d}, J=4.8 \mathrm{~Hz}, 1 \mathrm{H}), 8.69$ (d, $J=1.1 \mathrm{~Hz}, 1 \mathrm{H}), 7.92\left(\mathrm{dd}, J=5.0 \mathrm{~Hz}, J^{\prime}=1.7 \mathrm{~Hz}, 1 \mathrm{H}\right), 7.40$ (dd, $J=5.0 \mathrm{~Hz}$, $\left.J^{\prime}=1.9 \mathrm{~Hz}, 1 \mathrm{H}\right), 6.91(\mathrm{t}, J=2.2 \mathrm{~Hz}, 1 \mathrm{H}), 6.53\left(\mathrm{dd}, J=3.6 \mathrm{~Hz}, J^{\prime}=1.7 \mathrm{~Hz}, 1 \mathrm{H}\right)$, $6.29\left(\mathrm{dd}, J=3.0 \mathrm{~Hz}, J^{\prime}=2.2 \mathrm{~Hz}, 1 \mathrm{H}\right), 4.16(\mathrm{t}, J=7.5 \mathrm{~Hz}, 2 \mathrm{H}), 4.03(\mathrm{~s}, 3 \mathrm{H}), 4.02$ (s, 3H), $1.79(\mathrm{~m}, 2 \mathrm{H}), 1.23(\mathrm{~m}, 2 \mathrm{H}), 1.14(\mathrm{~m}, 4 \mathrm{H}), 0.71(\mathrm{t}, J=7.2 \mathrm{~Hz}, 3 \mathrm{H})$.

\section{Synthesis of dimethyl 4"-(2-hexyl-4-methylthiazol-5-yl)-[2,2':6',2"-} terpyridine] -4,4'-dicarboxylate (L39). The solution consisting of $0.22 \mathrm{~g}(0.51$ mmol) dimethyl 4"-bromo-[2,2':6',2"-terpyridine]-4,4'-dicarboxylate (11), $0.49 \mathrm{~g}$ (1.42 mmol) 2-hexyl-4-methyl-5-(trimethylstannyl)thiazole (7) and $0.036 \mathrm{~g}$ 
(0.031 mmol) $\mathrm{Pd}\left(\mathrm{PPh}_{3}\right)_{4}$ in $25 \mathrm{~mL}$ anhydrous DMF was stirred at $100{ }^{\circ} \mathrm{C}$ for 4 h. After cooling to RT, the solution was treated with the same procedures as described above for preparing L36. The crude product was purified using silica gel chromatography with $\mathrm{DCM} / \mathrm{MeOH}=25 / 1$ as an eluent to afford L39 as a yellow solid (0.165 g, 61.0\% yield). ${ }^{1} \mathrm{H}-\mathrm{NMR}\left(500 \mathrm{MHz}, \delta / p p m\right.$ in $\left.\mathrm{CDCl}_{3}\right): 9.15$ (s, 1H), $9.05(\mathrm{dd}, J=5.2 \mathrm{~Hz}, 1.4,2 \mathrm{H}), 8.89(\mathrm{~d}, J=5.1 \mathrm{~Hz}, 1 \mathrm{H}), 8.81(\mathrm{~d}, J=1.2$ Hz, 1H), $8.75(d, J=4.9 \mathrm{~Hz}, 1 \mathrm{H}), 7.93\left(\mathrm{dd}, J=4.9 \mathrm{~Hz}, J^{\prime}=1.5 \mathrm{~Hz}, 1 \mathrm{H}\right), 7.41$ (dd, $\left.J=5.1 \mathrm{~Hz}, J^{\prime}=1.8 \mathrm{~Hz}, 1 \mathrm{H}\right), 4.03(\mathrm{~d}, J=2.0 \mathrm{~Hz}, 6 \mathrm{H}), 3.02$ (t, $J=7.8 \mathrm{~Hz}$, 2H), $2.75(\mathrm{~s}, 3 \mathrm{H}), 1.84(\mathrm{~m}, 2 \mathrm{H}), 1.49-1.32(\mathrm{~m}, 8 \mathrm{H}), 0.90(\mathrm{t}, J=7.0 \mathrm{~Hz}, 3 \mathrm{H})$.

\section{Synthesis of dimethyl 4"-(4-hexyl-4H-thieno[3,2-b]pyrrol-2-yl)-[2,2':6',2"-} terpyridine]-4,4'-dicarboxylate (L41). The solution consisting of $0.6 \mathrm{~g}$ (1.40 mmol) dimethyl 4"-bromo-[2,2':6',2"-terpyridine]-4,4'-dicarboxylate (11), $0.79 \mathrm{~g}$ (2.13 mmol) 4-hexyl-2-(trimethylstannyl) -4H-thieno[3,2-b]pyrrole (10) and $0.043 \mathrm{~g}(0.037 \mathrm{mmol}) \mathrm{Pd}\left(\mathrm{PPh}_{3}\right)_{4}$ in $25 \mathrm{~mL}$ anhydrous DMF was stirred at 100 ${ }^{\circ} \mathrm{C}$ for $4 \mathrm{~h}$. After cooling to RT, the solution was treated with the same procedures as described above for preparing L36. The crude product was purified using silica gel chromatography with $\mathrm{DCM} / \mathrm{MeOH}=25 / 1$ as an eluent to afford L41 as a yellow solid $(0.49 \mathrm{~g}, 63.1 \%$ yield $) .{ }^{1} \mathrm{H}-\mathrm{NMR}(500 \mathrm{MHz}, \delta / \mathrm{ppm}$ in $\left.\mathrm{CDCl}_{3}\right): 9.23(\mathrm{~s}, 1 \mathrm{H}), 9.02\left(\mathrm{dd}, J=5.7 \mathrm{~Hz}, J^{\prime}=1.4 \mathrm{~Hz}, 1 \mathrm{H}\right), 8.89(\mathrm{~d}, J=4.8$ $\mathrm{Hz}, 1 \mathrm{H}), 8.83(\mathrm{~d}, J=1.4 \mathrm{~Hz}, 1 \mathrm{H}), 8.67(\mathrm{~d}, J=5.4 \mathrm{~Hz}, 1 \mathrm{H}), 8.69(\mathrm{~d}, J=1.1 \mathrm{~Hz}$, 1H), $7.92\left(\mathrm{dd}, J=4.9 \mathrm{~Hz}, J^{\prime}=1.5 \mathrm{~Hz}, 1 \mathrm{H}\right), 7.56(\mathrm{~s}, 1 \mathrm{H}), 7.55(\mathrm{~d}, J=1.9 \mathrm{~Hz}, 1 \mathrm{H})$, $6.95(\mathrm{~d}, J=2.9 \mathrm{~Hz}, 1 \mathrm{H}), 6.40(\mathrm{~d}, J=2.9 \mathrm{~Hz}, 1 \mathrm{H}), 4.10(\mathrm{t}, J=7.2 \mathrm{~Hz}, 2 \mathrm{H}), 4.04$ (s, 3H), $4.03(\mathrm{~s}, 3 \mathrm{H}), 1.88(\mathrm{~m}, 2 \mathrm{H}), 1.31(\mathrm{~m}, 6 \mathrm{H}), 0.87(\mathrm{t}, J=7.0 \mathrm{~Hz}, 3 \mathrm{H})$. 


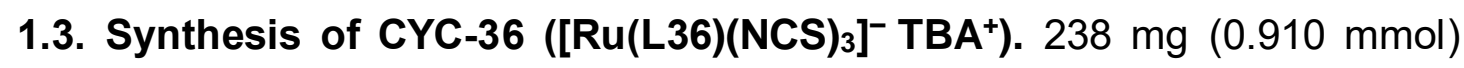
$\mathrm{RuCl}_{3} \cdot 3 \mathrm{H}_{2} \mathrm{O}$ in $35 \mathrm{~mL}$ anhydrous ethanol $(\mathrm{EtOH})$ was mixed $454 \mathrm{mg}(0.910$ mmol) L36 in trace DCM. The solution was refluxed for $4 \mathrm{~h}$ and then cooled to RT. After removing the solvents under reduced pressure, $35 \mathrm{~mL}$ deionized water was added. The precipitate was filtered and washed successively with cold EtOH and ether. After drying under vacuum, the solid was dissolved in the solution which consists of $2.08 \mathrm{~g}(27.33 \mathrm{mmol})$ ammonium thiocyanate $\left(\mathrm{NH}_{4} \mathrm{NCS}\right)$ and $40 \mathrm{~mL}$ anhydrous DMF. The mixture was refluxed for $4 \mathrm{~h}$, followed by being cooled to RT. After removing DMF under reduced pressure, $50 \mathrm{~mL}$ deionized water was added to get the precipitate. The solid was filtered, washed successively with deionized water and ether, and then dried under vacuum. In the hydrolysis of the solid, $2.8 \mathrm{~mL}$ tetrabutylammonium hydroxide solution ( $\mathrm{TBAOH} ; 40 \mathrm{wt} \%$ in $\mathrm{MeOH}$ ) and $70 \mathrm{~mL}$ acetone were used. The mixture was refluxed for $2 \mathrm{~h}$ and then cooled to RT. After removing acetone under reduced pressure, $200 \mathrm{~mL}$ deionized water was added. The $\mathrm{pH}$ value of the solution was adjusted to 1.0 using $1 \mathrm{M} \mathrm{HNO}_{3 \text { (aq.) }}$ for obtaining precipitate. The precipitate was filtered and washed sequentially with deionized water and ether. After drying under vacuum, the crude product was dissolved in a mixture of $\mathrm{MeOH}$ and $\mathrm{TBAOH}$ (40 wt\% in $\mathrm{MeOH}$ ) and purified with a Sephadex LH-20 column, using $\mathrm{MeOH}$ as an eluent. The main band was collected and the $\mathrm{pH}$ value of the concentrated solution was lowered to 1.0 by adding $1 \mathrm{M} \mathrm{HNO}_{3 \text { (aq.). }}$ The collected product was filtered and washed with deionized water. After drying under vacuum, the product was further purified on a C18 reversed-phase column (using acetonitrile $(\mathrm{ACN}) / \mathrm{H}_{2} \mathrm{O}=7 / 3$ as an eluent) for three times to obtain CYC-36 as a dark solid (130 mg, 14.5\% yield). ${ }^{1} \mathrm{H}-\mathrm{NMR}(500 \mathrm{MHz}, \delta / \mathrm{ppm}$ in DMSO-d $\mathrm{d}_{6}$; Figure S2): $9.09(\mathrm{~s}, 1 \mathrm{H}), 9.03(\mathrm{~s}, 3 \mathrm{H}), 8.80(\mathrm{~s}, 1 \mathrm{H}), 8.72(\mathrm{~d}, J=5.9$ 
$\mathrm{Hz}, 1 \mathrm{H}), 8.22(\mathrm{~d}, J=5.8 \mathrm{~Hz}, 1 \mathrm{H}), 7.90(\mathrm{~d}, J=5.8 \mathrm{~Hz}, 1 \mathrm{H}), 7.16(\mathrm{~s}, 1 \mathrm{H}), 6.88(\mathrm{~d}$, $J=2.0 \mathrm{~Hz}, 1 \mathrm{H}), 6.25(\mathrm{t}, J=2.9 \mathrm{~Hz}, 1 \mathrm{H}), 4.25(\mathrm{t}, J=7.1 \mathrm{~Hz}, 2 \mathrm{H}), 3.16(\mathrm{t}, J=8.3$ $\mathrm{Hz}, 8 \mathrm{H}), 1.65(\mathrm{~m}, 2 \mathrm{H}), 1.56(\mathrm{~m}, 8 \mathrm{H}), 1.30(\mathrm{~m}, 8 \mathrm{H}), 1.19(\mathrm{~m}, 6 \mathrm{H}), 0.92(\mathrm{t}, J=7.3$ $\mathrm{Hz}, 12 \mathrm{H}), 0.77(\mathrm{t}, J=7.1 \mathrm{~Hz}, 3 \mathrm{H}) .{ }^{13} \mathrm{C}-\mathrm{NMR}(125 \mathrm{MHz}, \delta / p p m$ in DMSO-d 6 ; Figure S3): 165.61, 165,08, 160.81, 160.21, 159.14, 157.91, 153.34, 152.11, $141.20,137.95,132.72,129.42,129.07,127.61,126.77,123.97,122.14$, $121.41,121.14,120.77,113.88,108.58,57.55,47.60,30.78,30.62,25.52$, 23.03, 21.88, 19.16, 13.72, 13.40. HRESI-TOF-MS (negative ion) calcd: for $\mathrm{C}_{30} \mathrm{H}_{26} \mathrm{~N}_{7} \mathrm{O}_{4} \mathrm{RuS}_{3}\left([\mathrm{M}]^{-}\right)$: 746.0258; found: 746.0258. Elemental analysis calcd (\%) for $\mathrm{C}_{46} \mathrm{H}_{62} \mathrm{~N}_{8} \mathrm{O}_{4} \mathrm{RuS}_{3} \cdot 2 \mathrm{H}_{2} \mathrm{O}: \mathrm{C}, 53.94 ; \mathrm{H}, 6.49 ; \mathrm{N}, 10.94 ; \mathrm{S}, 9.39$; found: C, 54.12; H, 6.32; N, 11.21; S, 9.14.

1.4. Synthesis of CYC-39 ([Ru(L39)(NCS) $\left.\left.]^{-}\right]^{-} \mathrm{TBA}^{+}\right)$. The synthesis and purification of CYC-39 were carried out using the same procedures as described above for preparing CYC-36, in which $0.17 \mathrm{~g}(0.650 \mathrm{mmol})$ $\mathrm{RuCl}_{3} \cdot 3 \mathrm{H}_{2} \mathrm{O}, 345 \mathrm{mg}(0.650 \mathrm{mmol})$ L39 and $1.49 \mathrm{~g}(19.57 \mathrm{mmol}) \mathrm{NH}_{4} \mathrm{NCS}$ were used. After purification, CYC-39 was obtained as a dark solid $(62.4 \mathrm{mg}, 9.4 \%$ yield). ${ }^{1} \mathrm{H}-\mathrm{NMR}\left(500 \mathrm{MHz}, \delta / p p m\right.$ in $\mathrm{MeOH}_{-} \mathrm{d}_{4}$; Figure S4): 9.21 (d, J=5.6 Hz, 1H), $9.02(\mathrm{~d}, J=5.8 \mathrm{~Hz}, 1 \mathrm{H}), 8.90\left(\mathrm{dd}, J=5.8 \mathrm{~Hz}, J^{\prime}=1.1 \mathrm{~Hz}, 3 \mathrm{H}\right), 8.54(\mathrm{~d}, J=$ $1.7 \mathrm{~Hz}, 1 \mathrm{H}), 8.23\left(\mathrm{dd}, J=5.7 \mathrm{~Hz}, J^{\prime}=1.7 \mathrm{~Hz}, 1 \mathrm{H}\right), 7.87\left(\mathrm{dd}, J=5.9 \mathrm{~Hz}, J^{\prime}=1.9\right.$ $\mathrm{Hz}, 1 \mathrm{H}), 3.28(\mathrm{~m}, 8 \mathrm{H}), 3.10(\mathrm{t}, J=7.6 \mathrm{~Hz}, 2 \mathrm{H}), 2.72(\mathrm{~s}, 3 \mathrm{H}), 1.87(\mathrm{~m}, 2 \mathrm{H}), 1.75$ $(\mathrm{m}, 8 \mathrm{H}), 1.5(\mathrm{~m}, 14 \mathrm{H}), 1.04(\mathrm{t}, J=7.4 \mathrm{~Hz}, 12 \mathrm{H}), 0.96(\mathrm{t}, J=7.1 \mathrm{~Hz}, 3 \mathrm{H}) .{ }^{13} \mathrm{C}-$ NMR (125 MHz, $\delta / p p m$ in MeOH-d 4 ; Figure S5): 174.03, 167.01, 166.59, 162.36, $162.25,161.08,160.28,155.11,154.46,151.83,142.45,139.73,138.39$, 134.39, 130.17, 128.88, 127.78, 127.20, 122.94, 122.36, 59.62, 49.51, 49.34, $49.17,49.00,48.83,48.66,48.49,34.13,32.64,31.14,29.85,24.84,23.61$, 
20.75, 16.79, 14.41, 13.98. HRESI-TOF-MS (negative ion) calcd for $\mathrm{C}_{30} \mathrm{H}_{26} \mathrm{~N}_{7} \mathrm{O}_{4} \mathrm{RuS}_{4}\left([\mathrm{M}]^{-}\right)$: 777.9978; found: 777.9980 . Elemental analysis calcd (\%) for $\mathrm{C}_{46} \mathrm{H}_{62} \mathrm{~N}_{8} \mathrm{O}_{4} \mathrm{RuS}_{4} \cdot 1 \mathrm{H}_{2} \mathrm{O}$ : C, 53.21; H, 6.21; N, 10.79; S, 12.35; found: C, 52.84; H, 6.04; N, 10.84; S, 12.39.

1.5. Synthesis of $\mathrm{CYC}-41\left(\left[\mathrm{Ru}(\mathrm{L41})(\mathrm{NCS})_{3}\right]^{-} \mathrm{TBA}^{+}\right)$. The preparation and purification of CYC-41 were carried out using the same procedures as described above for preparing CYC-36, in which $184 \mathrm{mg}$ (0.704 mmol) $\mathrm{RuCl}_{3} \cdot 3 \mathrm{H}_{2} \mathrm{O}, 390 \mathrm{mg}(0.704 \mathrm{mmol}) \mathrm{L} 41$ and $1.61 \mathrm{~g}(21.15 \mathrm{mmol}) \mathrm{NH}_{4} \mathrm{NCS}$ were used. After purification, CYC-41 was obtained as a dark solid (117 mg, 15.9\% yield). ${ }^{1} \mathrm{H}-\mathrm{NMR}(500 \mathrm{MHz}, \delta / \mathrm{ppm}$ in DMSO-d 6 ; Figure S6): 9.14 (s, 1H), 9.02 (d, $J=6.2 \mathrm{~Hz}, 3 \mathrm{H}), 8.99(\mathrm{~s}, 1 \mathrm{H}), 8.66(\mathrm{~d}, J=6.0 \mathrm{~Hz}, 1 \mathrm{H}), 8.37(\mathrm{~s}, 1 \mathrm{H}), 8.22(\mathrm{~d}, J=$ $5.5 \mathrm{~Hz}, 1 \mathrm{H}), 7.96(\mathrm{~d}, J=5.9 \mathrm{~Hz}, 1 \mathrm{H}), 7.28(\mathrm{~d}, J=2.8 \mathrm{~Hz}, 1 \mathrm{H}), 6.47(\mathrm{t}, J=2.8$ $\mathrm{Hz}, 1 \mathrm{H}), 4.18(\mathrm{t}, J=7.0 \mathrm{~Hz}, 2 \mathrm{H}), 3.16(\mathrm{t}, J=8.3 \mathrm{~Hz}, 8 \mathrm{H}), 1.86(\mathrm{~m}, 2 \mathrm{H}), 1.56(\mathrm{~m}$, 6H), 1.30 (m, 16H), 0.93 (t, $J=7.3 \mathrm{~Hz}, 12 \mathrm{H}), 0.86$ (t, $J=7.0 \mathrm{~Hz}, 3 \mathrm{H}) .{ }^{13} \mathrm{C}-\mathrm{NMR}$ (125 MHz, $\delta / p p m$ in DMSO-d 6 ; Figure S7): 165.69, 165.13, 160.71, 160.24, $159.09,157.95,153.29,152.47,143.79,139.94,137.96,135.17,129.84$, $129.66,129.46,126.85,125.31,122.14,121.78,121.53,121.05,112.62$, $100.49,57.53,47.88,30.80,30.70,30.25,25.85,23.06,22.08,19.21,13.90$, 13.49. HRESI-TOF-MS (negative ion) calcd for $\mathrm{C}_{32} \mathrm{H}_{26} \mathrm{~N}_{7} \mathrm{O}_{4} \mathrm{RuS}_{4}$ ([M]-): 801.9973; found: 801.9977. Elemental analysis calcd (\%) for $\mathrm{C}_{48} \mathrm{H}_{62} \mathrm{~N}_{8} \mathrm{O}_{4} \mathrm{RuS}_{4} \cdot 2 \mathrm{H}_{2} \mathrm{O}$ : C, 53.36; H, 6.16; N, 10.37; S, 11.87; found: C, 53.66; H, 6.09; N, 10.33; S, 11.65 . 


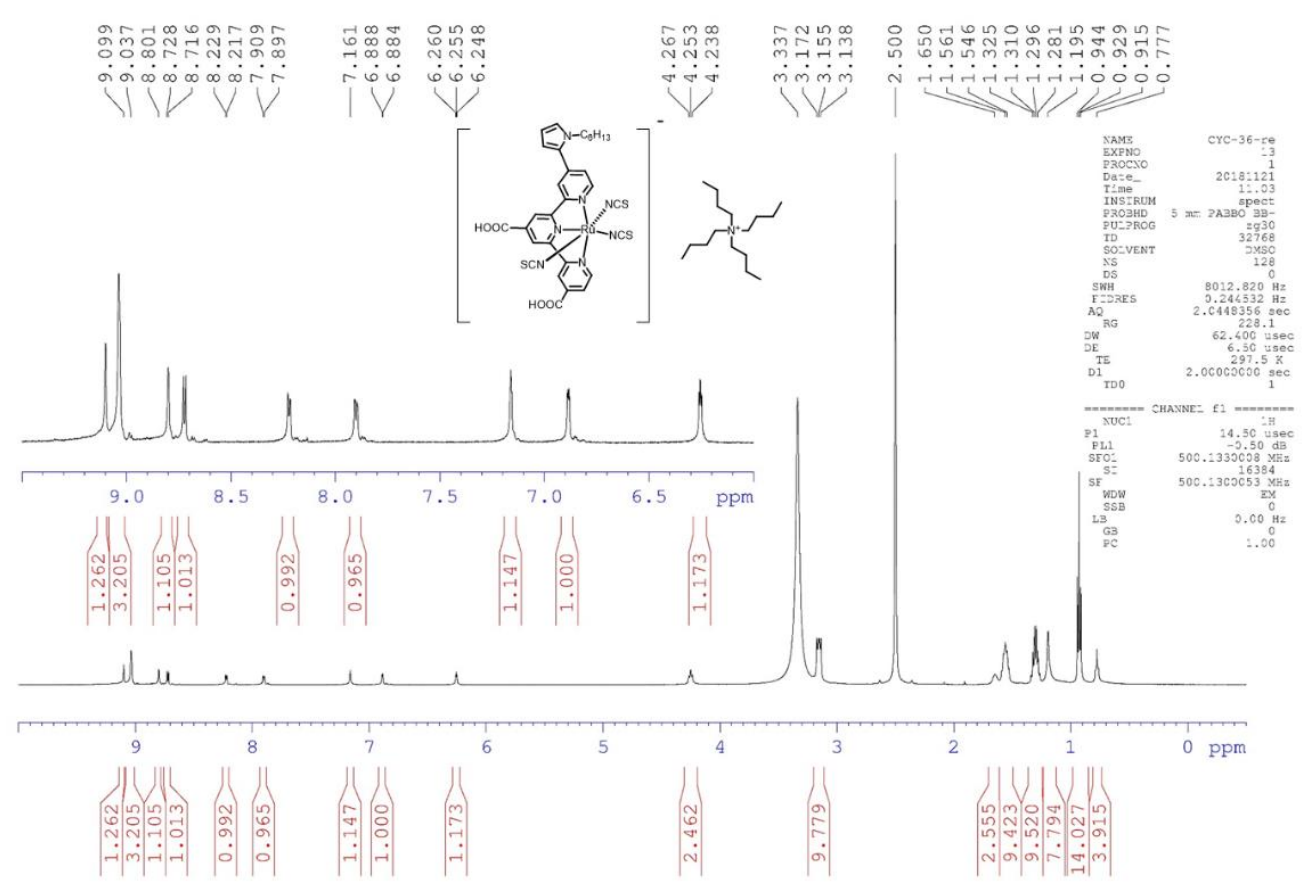

Figure S2. ${ }^{1} \mathrm{H}$ NMR spectrum of CYC-36 in DMSO- $\mathrm{d}_{6}$.

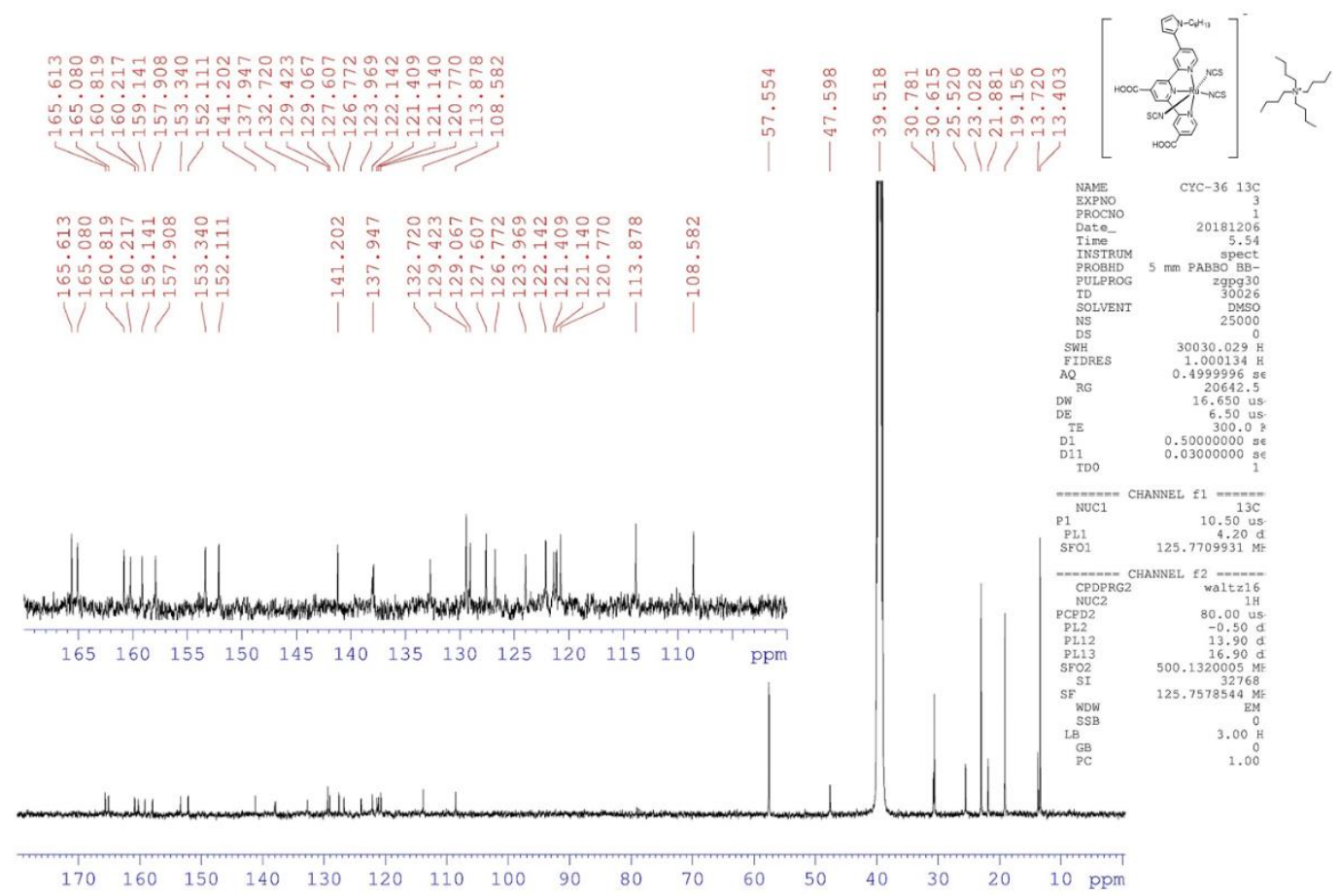

Figure S3. ${ }^{13} \mathrm{C}$ NMR spectrum of CYC-36 in DMSO-d 6 . 


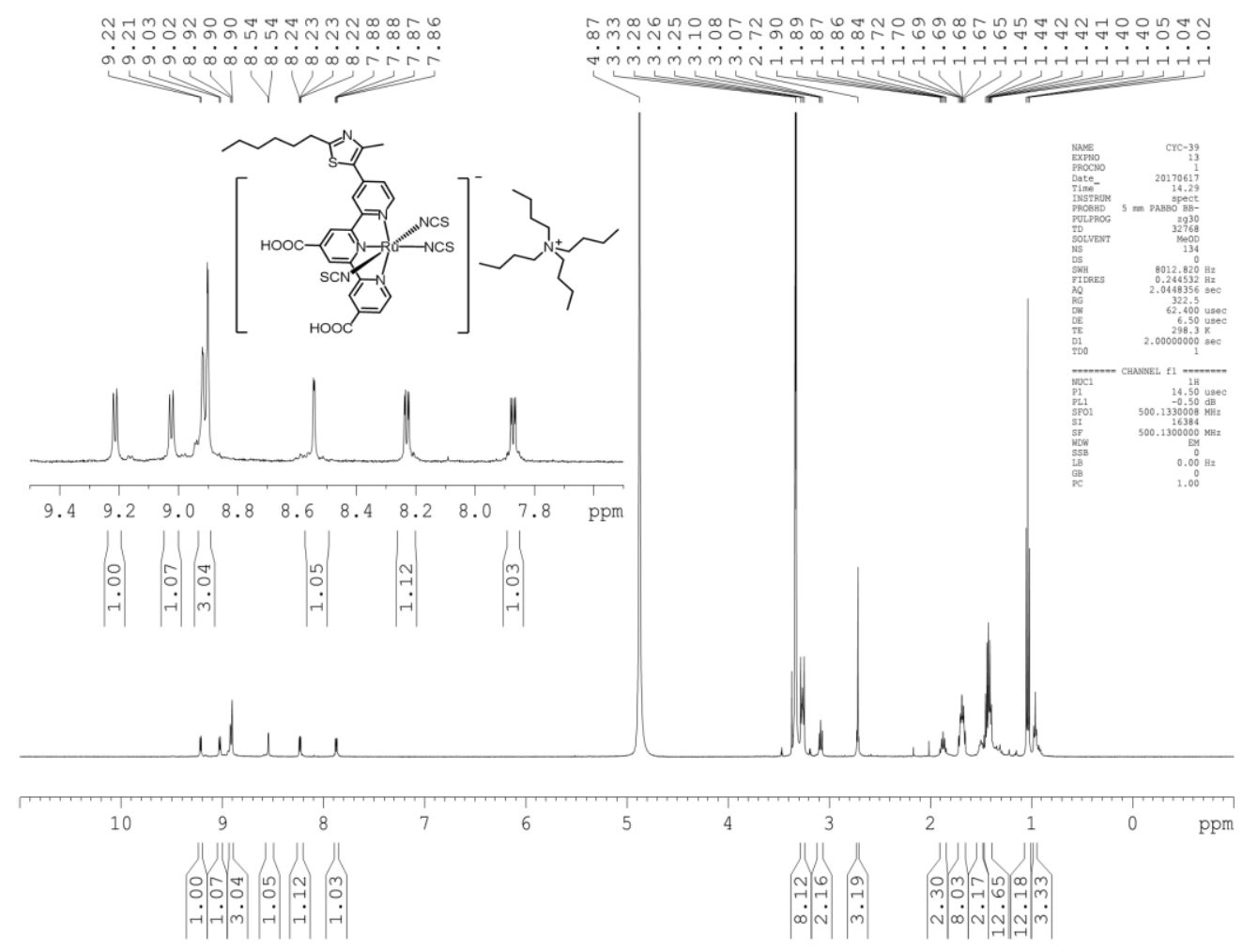

Figure S4. ${ }^{1} \mathrm{H}$ NMR spectrum of CYC-39 in $\mathrm{MeOH}-\mathrm{d}_{4}$.

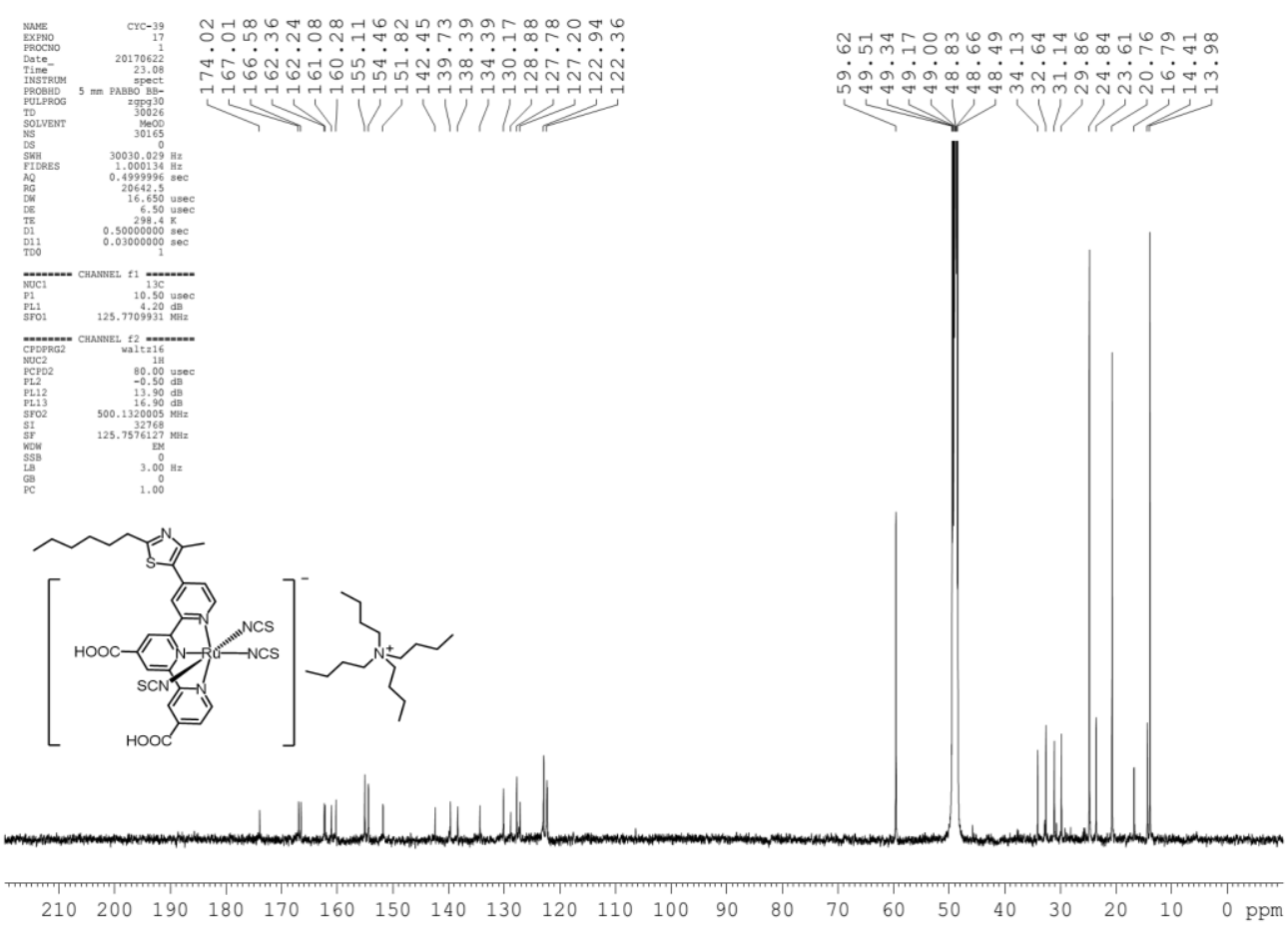

Figure S5. ${ }^{13} \mathrm{C}$ NMR spectrum of CYC-39 in $\mathrm{MeOH}-\mathrm{d}_{4}$. 


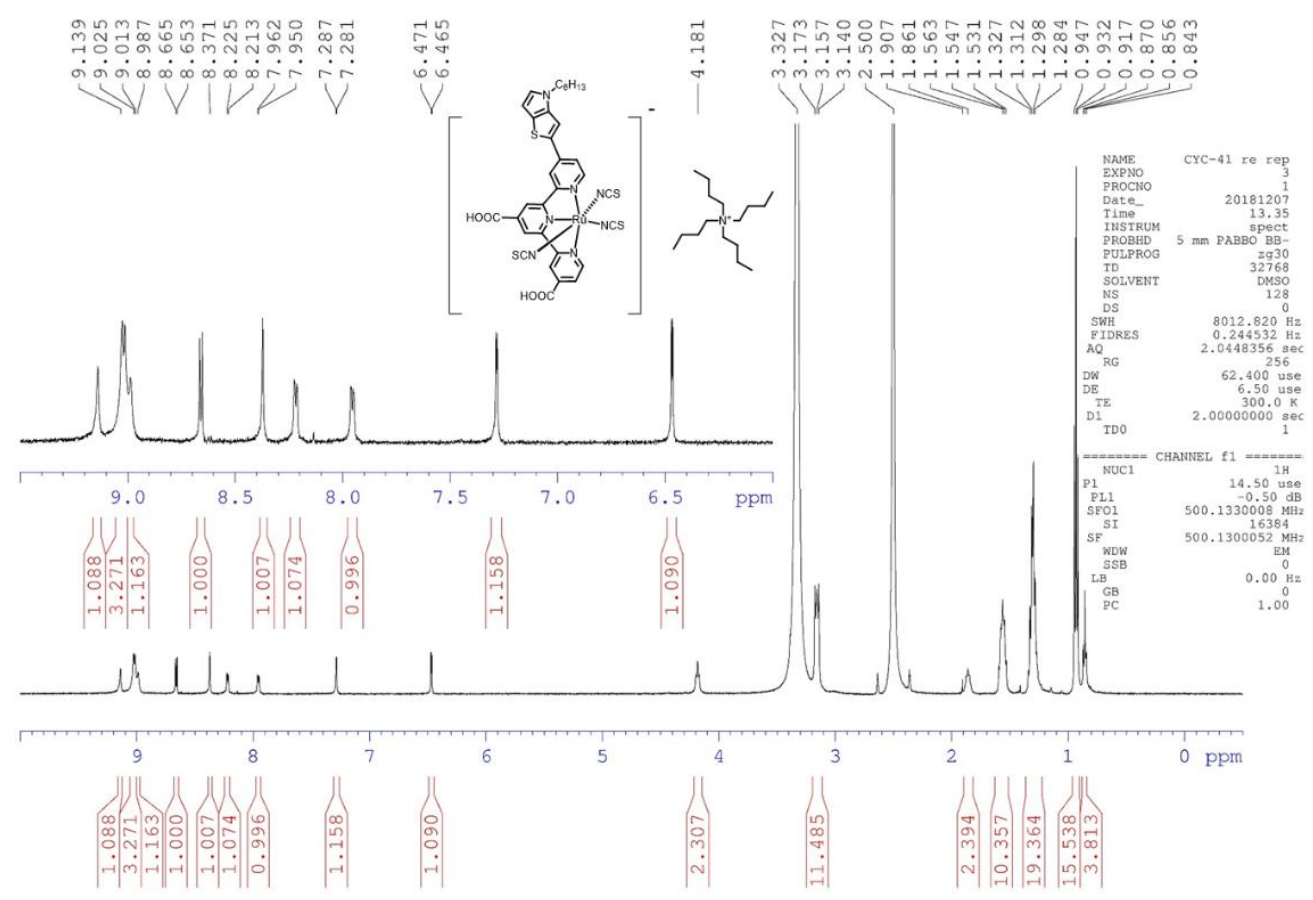

Figure S6. ${ }^{1} \mathrm{H}$ NMR spectrum of CYC-41 in DMSO- $\mathrm{d}_{6}$.

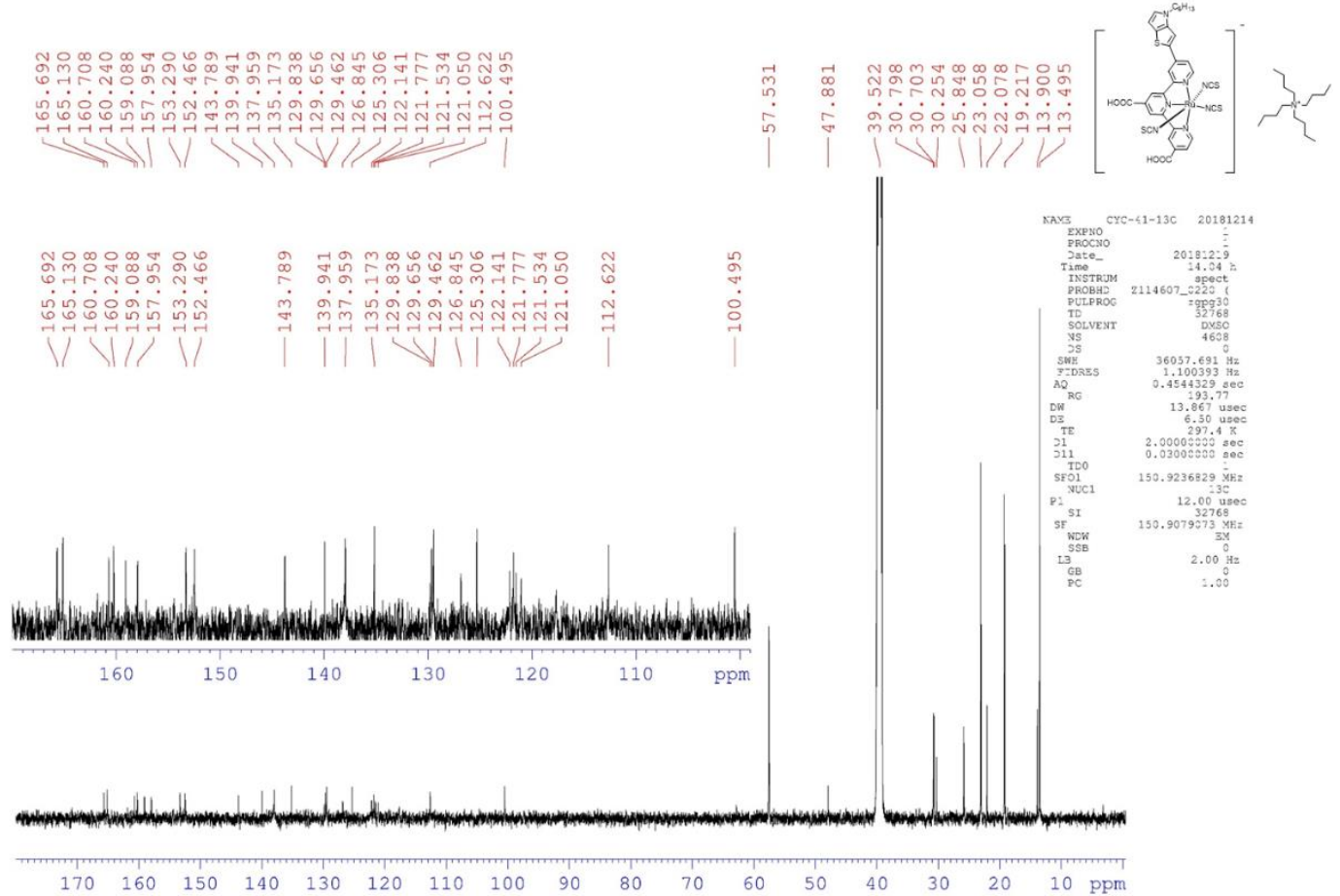

Figure S7. ${ }^{13} \mathrm{C}$ NMR spectrum of CYC-41 in DMSO-d $\mathrm{d}_{6}$. 
2. Supporting Figures and Table
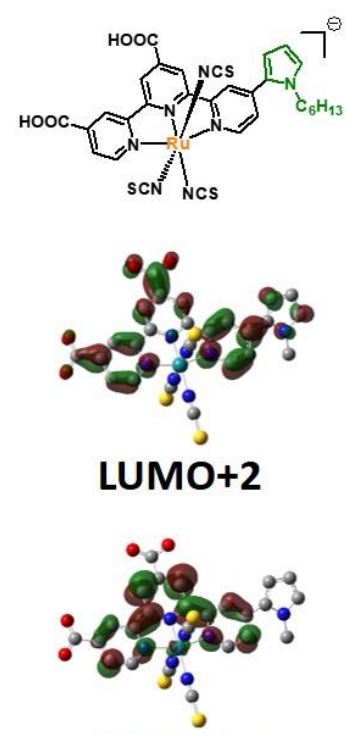

LUMO+1

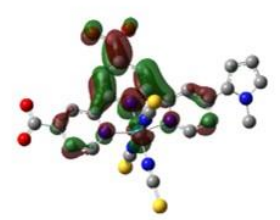

LUMO

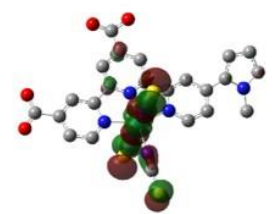

HOMO

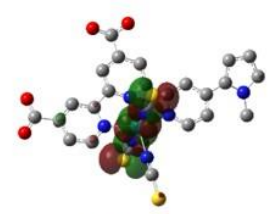

HOMO-1

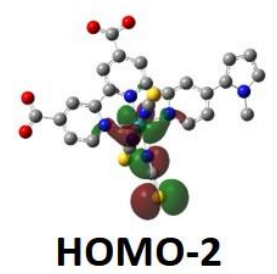

CYC-36
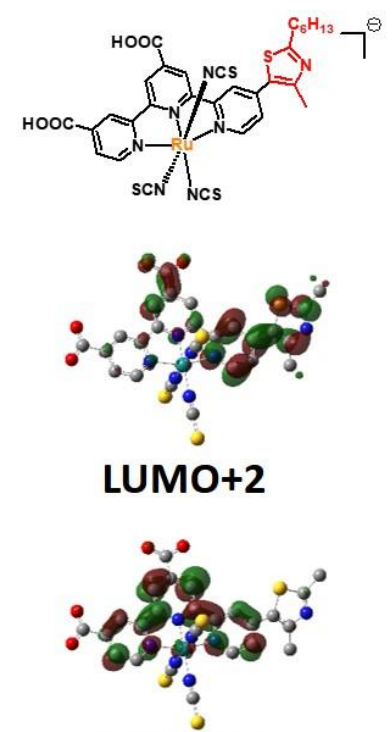

LUMO+1

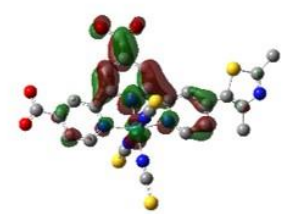

LUMO

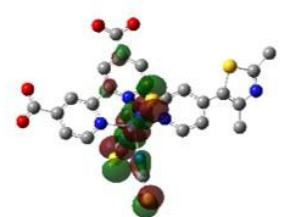

HOMO

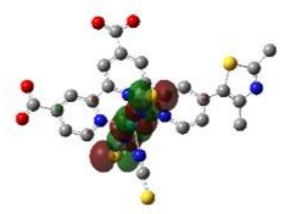

HOMO-1

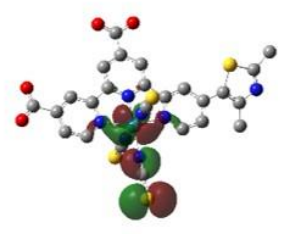

HOMO-2
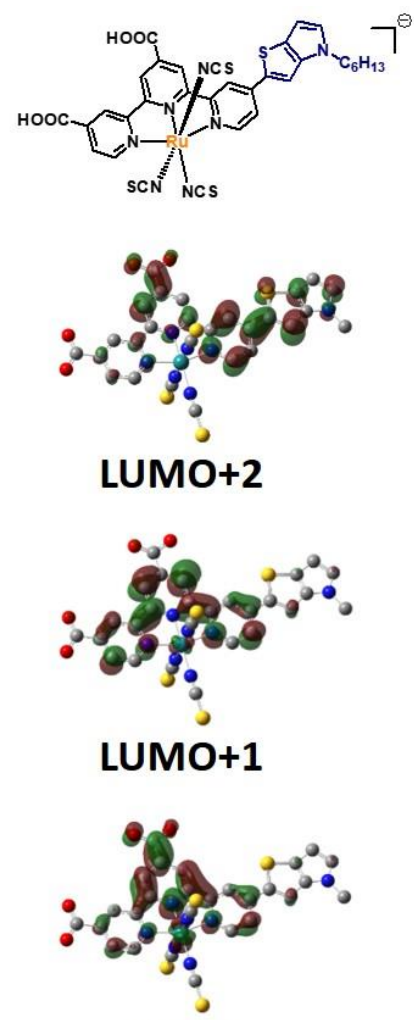

LUMO

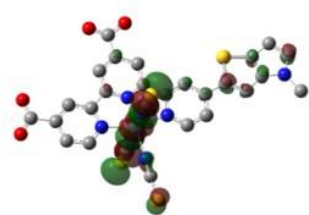

HOMO

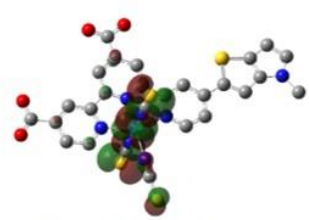

HOMO-1

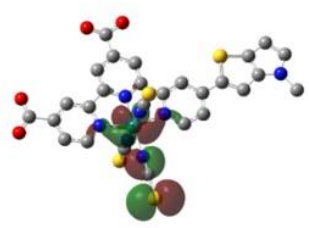

HOMO-2

CYC-41

Figure S8. Molecular structures and isodensity plots of frontier orbitals for CYC36, CYC-39 and CYC-41 calculated at the B3LYP/DGDZVP level (isovalue of 0.03 e $\left.\AA^{-3}\right)$. The hexyl terminals in the three dyes were replaced with methyl groups to save the computational cost. 


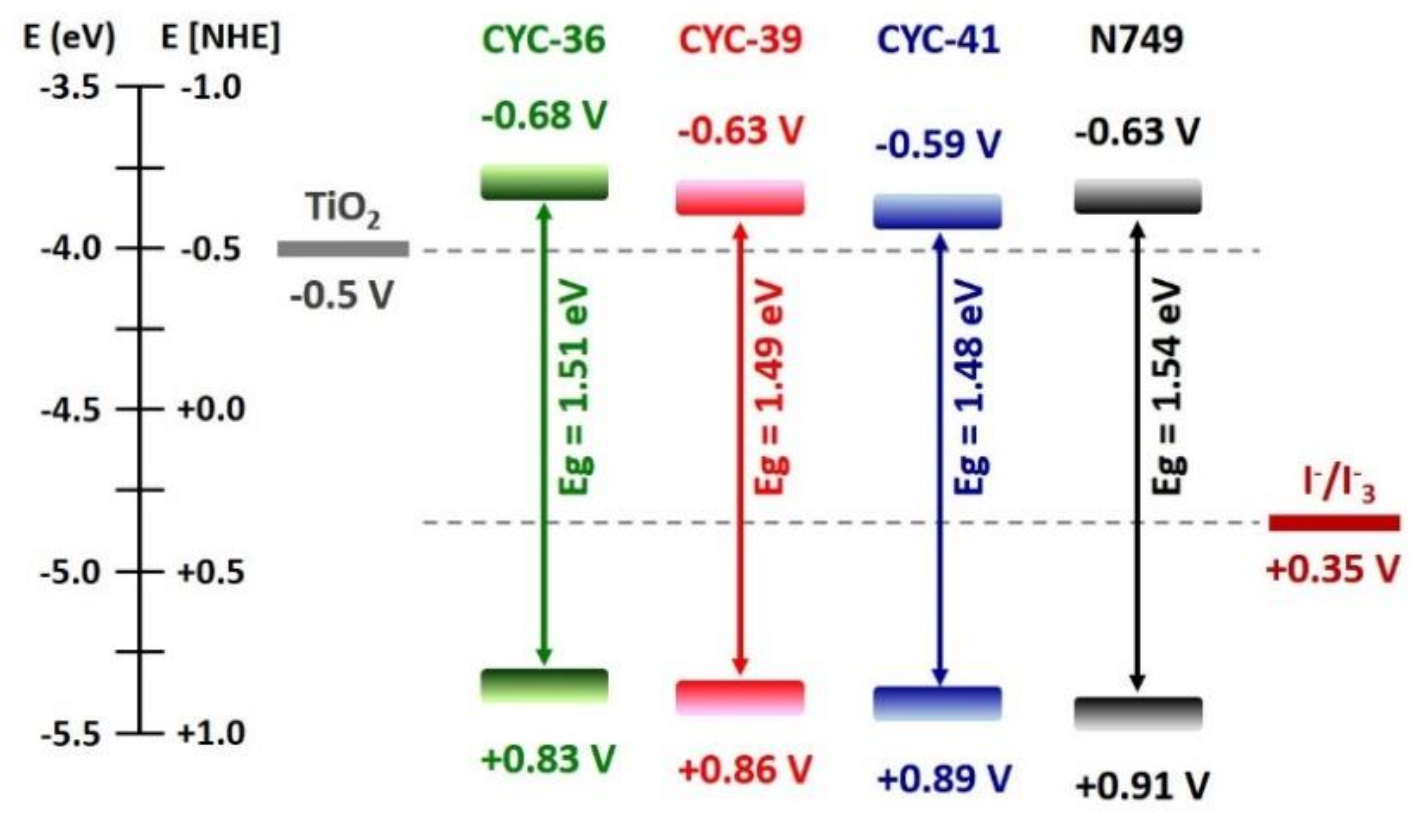

Figure S9. Energy level diagram of CYC-36, CYC-39, CYC-41, N749, $\mathrm{TiO}_{2}$ and $1-/ l_{3}^{-}$.

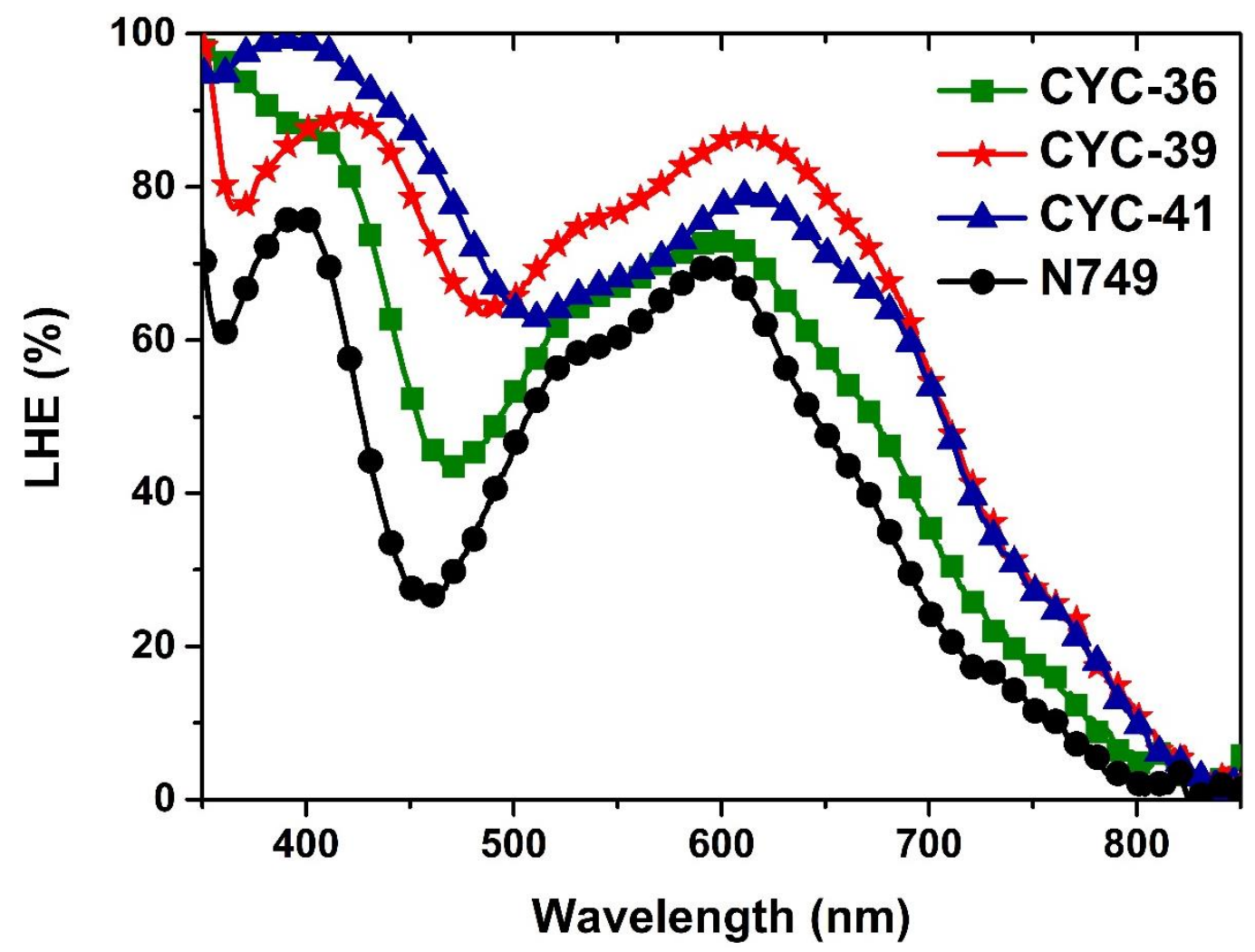

Figure S10. Light-harvesting efficiency (LHE) spectra of $\mathrm{TiO}_{2}$ electrodes sensitized with CYC-36, CYC-39, CYC-41 and N749, respectively. 

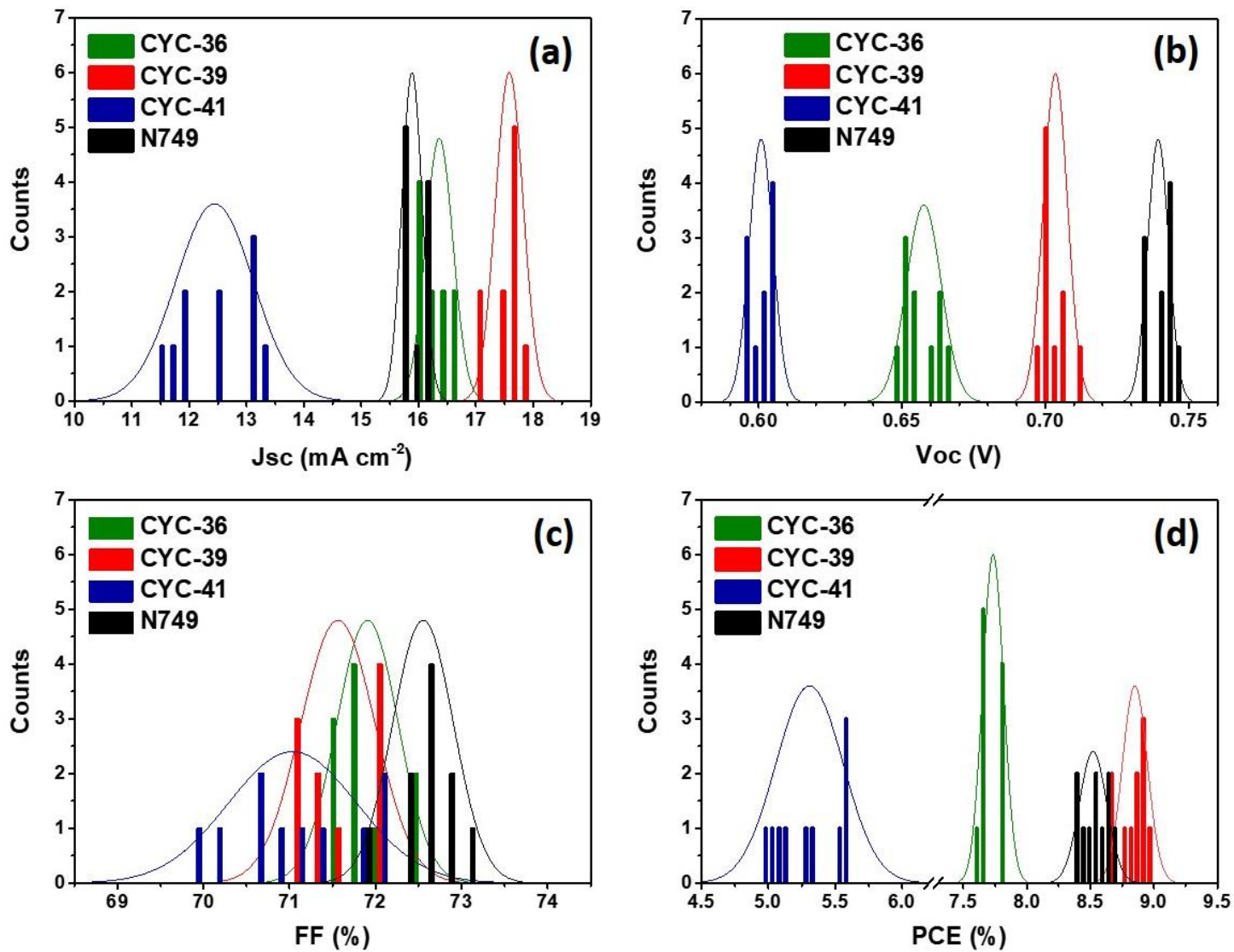

Figure S11. Histograms of (a) Jsc, (b) Voc, (c) FF and (d) PCE of the devices sensitized with CYC-36, CYC-39, CYC-41 and N749, respectively. 


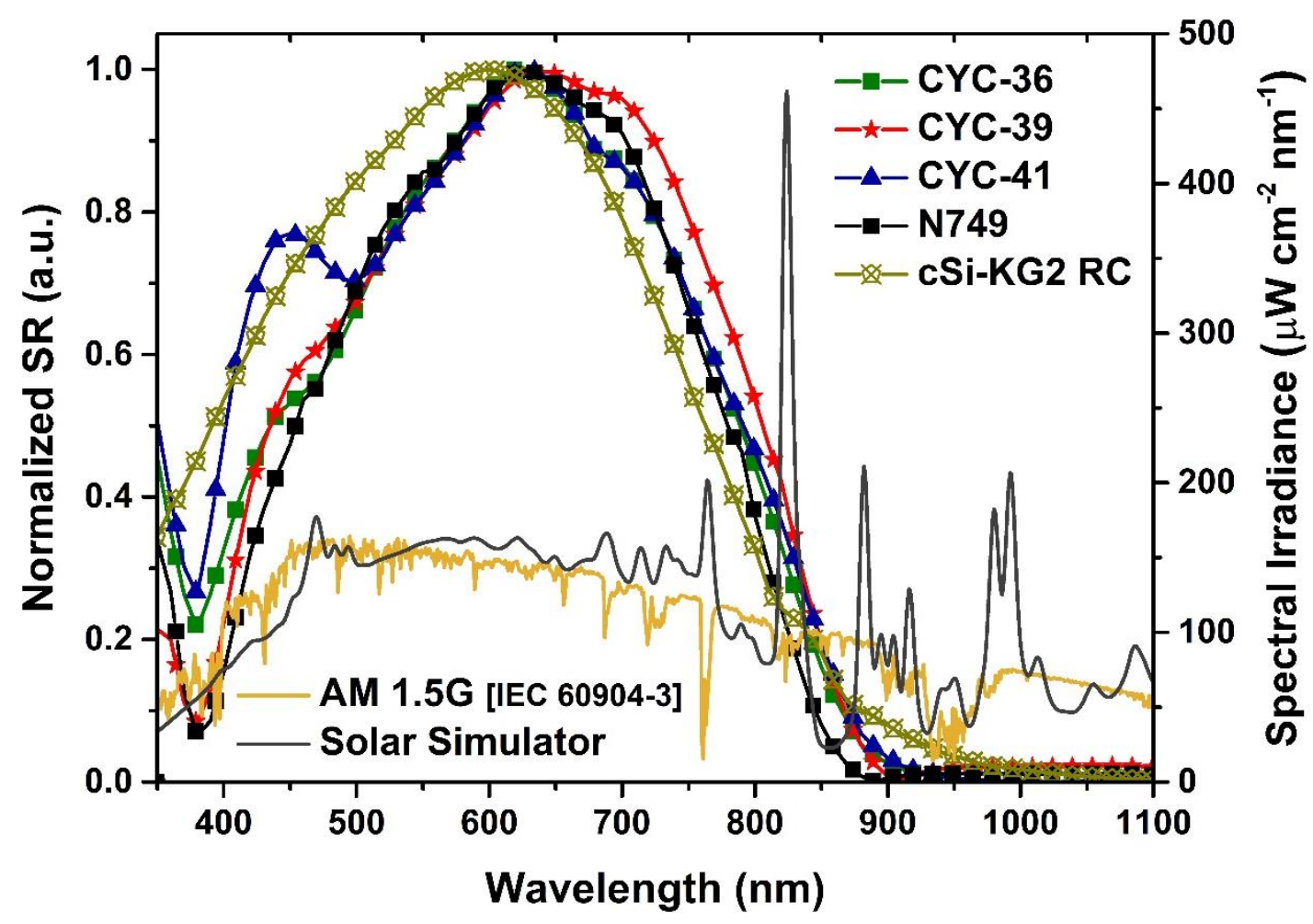

Figure S12. AM 1.5 global standard spectrum, spectral irradiance of the steady-state solar simulator used in this study, as well as the normalized spectral responsivities (SR) of the KG2-filtered single crystalline silicon photovoltaic reference cell (cSi-KG2 RC) and the devices sensitized with various Ru dyes.

Table S1. The spectral mismatch factors (SMMs) of devices sensitized with various $\mathrm{Ru}$ dyes

\begin{tabular}{ccccc}
\hline Devices & CYC-36 & CYC-39 & CYC-41 & N749 \\
\hline SMM & 1.0242 & 1.0355 & 1.0123 & 1.0294 \\
\hline
\end{tabular}



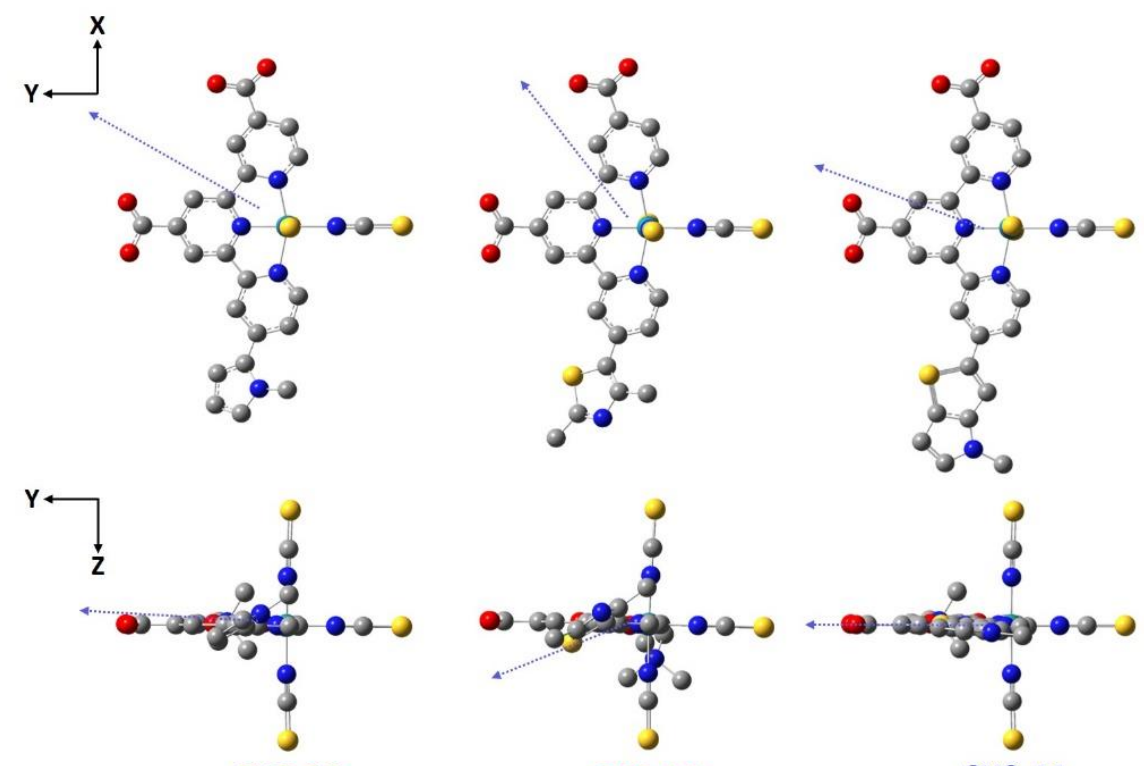

CYC-36

CYC-39

CYC-41

( $\left.\mu_{\mathrm{y}}=23.9 \mathrm{D}\right)$

( $\left.\mu_{y}=17.8 \mathrm{D}\right)$

( $\left.\mu_{\mathrm{y}}=24.6 \mathrm{D}\right)$

Figure S13. Molecular geometry and molecular dipole moment along the y-axis in the principle molecular axis ( $\mu_{y}$; nearly parallel to the central axis of carboxylated pyridine-Ru-NCS) of CYC-36, CYC-39 and CYC-41 calculated at the B3LYP/DGDZVP level. The arrows indicate the direction (from negative to positive) of net dipole moment for each Ru complex.
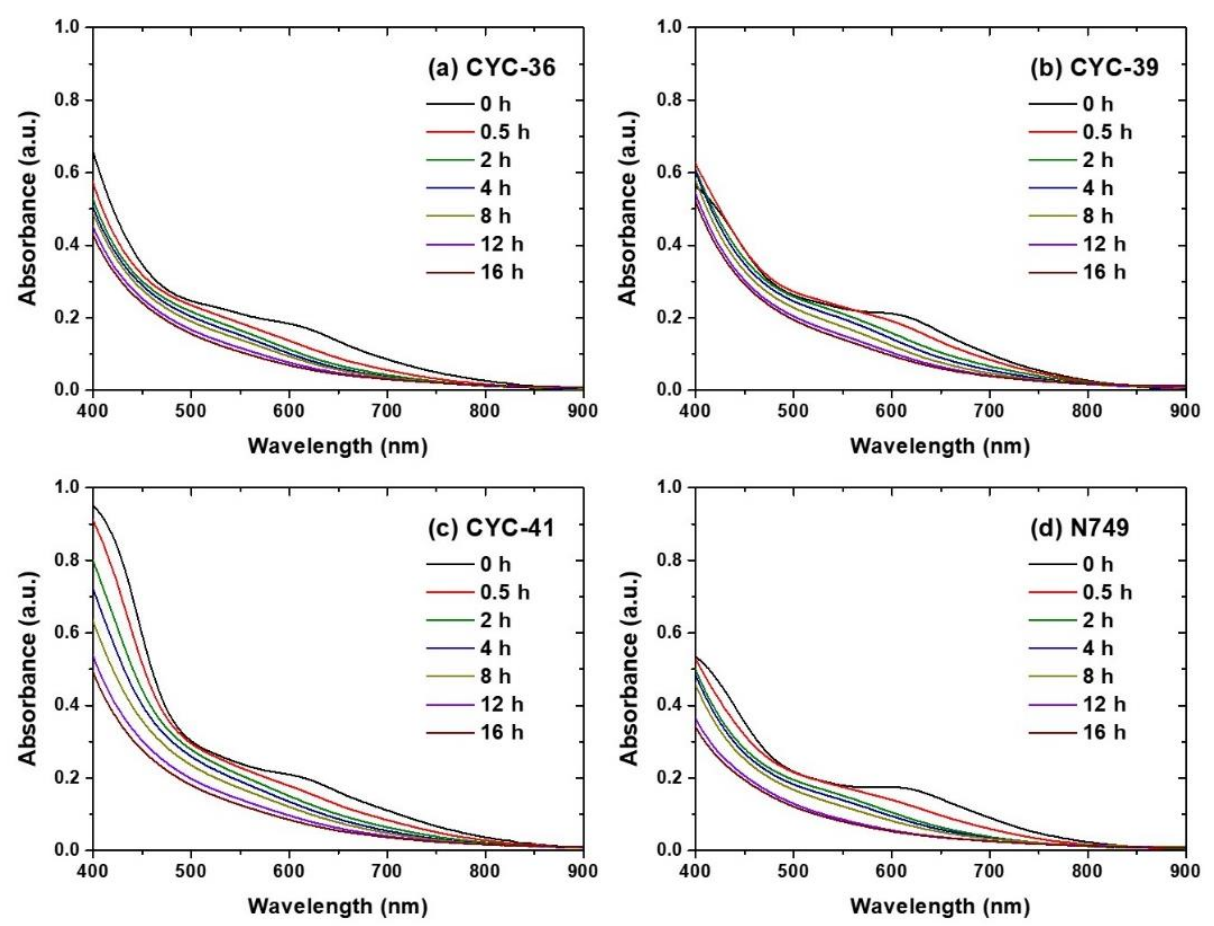

Figure S14. Absorption spectra of the $\mathrm{TiO}_{2}$ thin-films sensitized with various $\mathrm{Ru}$ complexes under continuous irradiation of the AM 1.5 global simulated sunlight and thermal stress of $45^{\circ} \mathrm{C}$. 


\section{Supporting References}

(S1) Brockmann, T. W.; Tour, J. M. Synthesis and Properties of Low-Bandgap Zwitterionic and Planar Conjugated Pyrrole-Derived Polymeric Sensors: Reversible Optical Absorption Maxima from the UV to the Near-IR. J. Am. Chem. Soc. 1995, 117, 4438-4447.

(S2) Nguyen, H. Q.; Rainbolt, E. A.; Sista, P.; Stefan, M. C. Synthesis and Polymerization of Fused-Ring Thienodipyrrole Monomers. Macromol. Chem. Phys. 2012, 213, 425-430.

(S3) Srinivasan, S.; Schuster, G. B. A Conjoined Thienopyrrole Oligomer Formed by Using DNA as a Molecular Guide. Org. Lett. 2008, 10, 3657-3660.

(S4) Jones, C.; Boudinet, D.; Xia, Y.; Denti, M.; Das, A.; Facchetti, A.; Driver, T. G. Synthesis and Properties of Semiconducting Bispyrrolothiophenes for Organic Field-Effect Transistors. Chem. Eur. J. 2014, 20, 5938-5945.

(S5) Eom, Y. K.; Kang, S. H.; Choi, I. T.; Yoo, Y.; Kim, J.; Kim, H. K. Significant Light Absorption Enhancement by a Single Heterocyclic Unit Change in the $\pi$-Bridge Moiety from Thieno[3,2- $b]$ benzothiophene to Thieno[3,2b]indole for High Performance Dye Sensitized and Tandem Solar Cells. J. Mater. Chem. A 2017, 5, 2297-2308. 